\title{
Article \\ Effect of Ethanol on Parthenogenetic Activation and $\alpha$-Tocopherol Supplementation during In Vitro Maturation on Developmental Competence of Summer-Collected Bovine Oocytes
}

\author{
Francisco Báez $^{1, *(\mathbb{D})}$, Belén Gómez ${ }^{1}$, Victoria de Brun ${ }^{2} \mathbb{D}$, Nélida Rodríguez-Osorio ${ }^{3} \mathbb{D}$ and Carolina Viñoles ${ }^{4}(\mathbb{D}$ \\ 1 Instituto Superior de la Carne, Centro Universitario Regional Noreste, Universidad de la República, Ruta 5, \\ km 386, Tacuarembó 45000, Uruguay; belugoma@gmail.com \\ 2 Laboratorio de Endocrinología y Metabolismo Animal, Universidad de la República, Laspalces 1620, \\ Montevideo 45000, Uruguay; videbrun@gmail.com \\ 3 Unidad de Genómica y Bioinformática, Departamento de Ciencias Biológicas, Centro Universitario Regional \\ Litoral Norte, Universidad de la República, Rivera 1350, Salto 50000, Uruguay; \\ nelida.rodriguez@unorte.edu.uy \\ 4 Centro de Salud Reproductiva de Rumiantes en Sistemas Agroforestales, Centro Universitario Regional \\ Noreste, Universidad de la República, Ruta 26, km 408, Cerro Largo 37000, Uruguay; \\ carolinavinolesgil@gmail.com \\ * Correspondence: francisco.baez@cut.edu.uy
}

Citation: Báez, F.; Gómez, B.; de Brun, V.; Rodríguez-Osorio, N.; Viñoles, C. Effect of Ethanol on Parthenogenetic Activation and $\alpha$-Tocopherol Supplementation during In Vitro Maturation on Developmental Competence of Summer-Collected Bovine Oocytes. Curr. Issues Mol. Biol. 2021, 43, 2253-2265. https://doi.org/10.3390/ cimb43030158

Academic Editor: Anna Kawiak

Received: 30 November 2021 Accepted: 13 December 2021 Published: 16 December 2021

Publisher's Note: MDPI stays neutral with regard to jurisdictional claims in published maps and institutional affiliations.

Copyright: () 2021 by the authors. Licensee MDPI, Basel, Switzerland. This article is an open access article distributed under the terms and conditions of the Creative Commons Attribution (CC BY) license (https:// creativecommons.org/licenses/by/ $4.0 /)$.

\begin{abstract}
The use of $\alpha$-tocopherol during in vitro maturation (IVM) is an alternative to minimize the adverse effects of heat stress on oocyte competence. However, $\alpha$-tocopherol is diluted in ethanol, which can induce oocyte parthenogenetic activation (PA). This study aimed to evaluate the role of ethanol concentration on PA and the effect of $\alpha$-tocopherol supplementation during IVM on the developmental competence and the expression of key genes in blastocysts derived from summercollected oocytes. All in vitro embryo production was conducted at $5 \% \mathrm{O}_{2}, 5 \% \mathrm{CO}_{2}$ at $38.5{ }^{\circ} \mathrm{C}$. Experiment 1: oocytes were cultured with or without $0.05 \%$ ethanol. As positive PA control matured oocytes were subjected to $3 \%$ or $7 \%$ ethanol for $7 \mathrm{~min}$. Oocytes from all groups were placed in fertilization medium (22 h) and culture medium (9 days). Ethanol at $0.05 \%$ during IVM did not induce oocyte PA, however, $3 \%$ and $7 \%$ ethanol were effective parthenogenetic inductors. Experiment 2: oocytes were cultured in maturation medium supplemented with $0,50,100$ and $200 \mu \mathrm{M} \alpha-$ tocopherol, diluted in $0.05 \%$ ethanol. After in vitro fertilization and embryo culture, we assessed blastocyst apoptotic index and the transcription of a panel of genes. The results showed that supplementation with $100 \mu \mathrm{M} \alpha$-tocopherol reduced apoptotic index and increased the expression of SOD2. In conclusion, $100 \mu \mathrm{M} \alpha$-tocopherol, diluted in $0.05 \%$ ethanol, can be used during IVM to embryonic quality.
\end{abstract}

Keywords: antioxidant; quality blastocysts; summer; gene expression

\section{Introduction}

During summer, in temperate regions, grazing beef cows are exposed to acute heat stress [1], which can result in multiple physiological and cellular changes that reduce reproductive performance [2,3]. Heat stress can compromise fertility in cattle by inducing alterations in the steroidogenic capacity of the follicles. It can also cause ovulation defects, affecting oocyte competence and preimplantation embryonic development [4]. Despite the multiple detrimental effects of heat stress on the hypothalamus-pituitary-ovarian axis [5-7], there is increasing in vivo and in vitro evidence that oocytes are also significant targets of maternal heat stress [8]. Thus, several studies have confirmed that cumulus oocyte complexes (COCs) collected during summer show lower quality [3,9-11] and compromised 
developmental competence after in vitro fertilization, suggesting that summer heat stress may potentially impair oocyte quality [12,13].

One of the mechanisms by which heat stress appears to induce damage to the oocyte and developing embryo is an increase in the production of reactive oxygen species (ROS) [14]. Although ROS can regulate cell function and activate key signaling pathways [15], in excess they are also implicated in many types of cell injuries such as membrane lipid peroxidation, oxidation of nucleic acids, apoptosis and necrosis [16]. One approaches to combat the effect of heat stress on bovine oocyte developmental competence is adding thermoprotective or antioxidant molecules during in vitro maturation (IVM). Vitamin E or $\alpha$-tocopherol is a natural antioxidant that provides cell defense against oxidative stress [17]. Previous studies reported an increase in blastocyst yield in sheep [18], pig [16], and cattle [19] with the addition of this molecule during in vitro culture (IVC). Supplementation of IVM medium with $\alpha$-tocopherol reduced apoptotic rate in rabbit [20] and porcine [21] cumulus cells and improved oocyte developmental competence. However, the expression of genes involved in the processes of heat and oxidative stress response (SOD2, CAT and HSPA1A), pro- and anti-apoptotic activity ( $B A X$ and $B C L 2)$, and maternal recognition of pregnancy (IFNT2) has not been described in $\alpha$-tocopherol-treated embryos, and its evaluation can provide insights into its mechanism of action [22].

Due to its hydrophobic nature, $\alpha$-tocopherol is first diluted in absolute ethanol, to obtain a final $25-400 \mu \mathrm{M} \alpha$-tocopherol concentration and $0.05 \%(v / v)$ ethanol in culture media. Ethanol is a known parthenogenesis activator at concentrations above 3\% [23], and when associated with other molecules is used in long protocols to produce parthenogenetic embryos [24]. Although $1 \%$ ethanol and $20 \% \mathrm{O}_{2}$ have been found to be inefficient in promoting parthenogenetic activation in bovine oocytes [23], a recent study reported that adding $0.3 \%$ ethanol to the IVM medium increased blastocyst rate, regardless of culture conditions [25]. Other studies have tested ethanol as the vehicle for the dilution of different molecules, during oocyte culture [14], but few systematic studies have investigated the role of ethanol at such low concentrations on parthenogenetic activation and embryonic development. Therefore, it is necessary to evaluate if, under physiological oxygen tension, $0.05 \%(v / v)$ ethanol can induce parthenogenetic activation in immature oocytes, in comparation with a high concentration of ethanol for a few minutes as a positive control, to promote parthenogenetic development in oocytes.

Although the beneficial effect of $\alpha$-tocopherol in mammalian oocytes has been investigated, to date there are no studies on the effect of $\alpha$-tocopherol (and $0.05 \%$ ethanol) supplementation during IVM and their influence on the competence of bovine oocytes collected during summer. We hypothesized that during IVM the supplementation with ethanol at $0.05 \%(v / v)$ does not promote parthenogenetic activation, but ethanol at 3 and $7 \%$ for $7 \mathrm{~min}$ is an effective inductor of parthenogenesis. Additionally, ethanol-diluted $\alpha$-tocopherol improves the yield and quality of bovine embryos, which is reflected in the expression of target genes. The objectives of this study were to (1) measure the role of ethanol on parthenogenic activation during IVM of bovine oocytes collected during summer, and to (2) determine how $\alpha$-tocopherol supplementation during in vitro maturation of oocytes, collected during summer, affects their nuclear maturation, fertilization rate, and the subsequent development and the expression of SOD2, CAT, HSPA1A, BAX, BCL2 and IFNT2 in the resulting embryos.

\section{Materials and Methods}

Reagents: all chemicals were purchased from Sigma-Aldrich (St. Louis, MO, USA), unless otherwise indicated.

\subsection{Sample Collection}

In this study, experiments were performed using bovine oocytes aspirated from ovaries obtained from a local slaughterhouse during summer in the southern hemisphere (between 21 December 2020 to 9 March 2021). Maximal and minimal temperatures and 
relative humidity were obtained from two meteorological stations of the National Research Institute for Agriculture (INIA-Uruguay), Agroclimatic Bank located in the north of the country: Salto $\left(31^{\circ} 16^{\prime} 22^{\prime \prime} \mathrm{S}, 57^{\circ} 53^{\prime} 27^{\prime \prime} \mathrm{W}\right)$ and Tacuarembó $\left(31^{\circ} 42^{\prime} 32^{\prime \prime} \mathrm{S}, 55^{\circ} 49^{\prime} 36^{\prime \prime} \mathrm{W}\right)$. The temperature-humidity index (THI) was calculated using the following equation:

$$
T H I=(0.8 \times T+(R H(\%) / 100)(T-14.4)+46.4)
$$

where $T$ is air temperature in degrees Celsius and $R H$ is relative humidity [26].

Pools of 35-45 ovaries were transported to the laboratory in a thermal container with $0.9 \% \mathrm{NaCl}(w / v)$ at $37{ }^{\circ} \mathrm{C}$ within 45 min of dissection. Cumulus-oocyte complexes (COCs) were aspirated from 2 to $8 \mathrm{~mm}$-diameter follicles. For each repeat, around of $150 \mathrm{COCs}$ with homogeneous cytoplasm and compact layers of cumulus cells were selected. All phases of in vitro embryo production were conducted at low oxygen tension $\left(5 \% \mathrm{O}_{2}\right)$, a concentration closer to the oxygen content in the follicle and female reproductive tract [27].

\subsection{Experimental Design}

\subsubsection{Experiment 1}

For evaluation of parthenogenetic activation of bovine oocytes in the presence of ethanol, a total of 826 COCs were used in six independent repeats. Selected COCs were maturated in vitro with ethanol at $0.05 \%(v / v)(n=242)$ and without ethanol $(n=584)$ for $24 \mathrm{~h}$. After in vitro maturation (IVM), 50-51 COCs per group were randomly denuded of cumulus cells, fixed, and processed for Hoechst DNA staining to determine meiotic progression. Matured COCs in the absence of alcohol were distributed into the control group $(n=180)$ and two groups that were activated with $3 \%(n=176)$ and $7 \%(n=178)$ ethanol $(v / v)$ in holding media solution at $38{ }^{\circ} \mathrm{C}$ for $7 \mathrm{~min}$. All groups were washed twice in holding media and cultured for $22 \mathrm{~h}$ in IVF-TL in absence of spermatozoa. After this period, a total of 48-53 oocytes per group were fixed and stained to determine pronuclei formation. The remaining oocytes (125-138 per group) were cultured in vitro for 9 days. Cleavage and blastocyst rates were determined on the third, seventh and ninth culture days, respectively. At the end of culture, embryos with a visible blastocoel were considered to be blastocysts. Parthenogenetic blastocysts of all groups (2-9 per treatments) were fixed and stained, and nuclei numbers were counted.

\subsubsection{Experiment 2}

To examine the effects of $\alpha$-tocopherol during IVM on the developmental capacity of bovine COCs, a total of 1818 COCs were used in eight independents repeats, divided into five treatments, and placed in maturation medium supplemented with different concentrations $(0,0.05 \%$ ethanol, 50, 100 and $200 \mu \mathrm{M})$ of $\alpha$-tocopherol $(v / v)$ for $24 \mathrm{~h}$ at $38.5{ }^{\circ} \mathrm{C}$ and $5 \% \mathrm{CO}_{2}, 5 \% \mathrm{O}_{2}$ and $90 \% \mathrm{~N}_{2}$. After this period, a group of oocytes ( $n=59-73$ per treatment) were denuded of cumulus cells and stained to evaluate meiotic progression. Then, 1482 COCs were fertilized in vitro. From those, 353 presumptive zygotes ( $n=66-73$ per treatment) were denuded, fixed, and stained to determine fertilization rate. The remaining presumptive zygotes $(n=208-244$ per treatment) were cultured in vitro and embryo development was assessed at day 3 (\% cleavage) and day 9 (\% early, expanded, and hatched blastocysts). On day 9, 10 expanded blastocysts per treatment were used for measuring the relative expression of genes involved in oxidative stress (CAT and SOD2), heat shock (HSPA1A), maternal recognition of pregnancy (IFNT2) and apoptosis (BAX and $B C L 2)$. Finally, expanded (11-14 per treatment) blastocysts were used for total cell number and apoptotic index evaluation through Terminal deoxynucleotidyl transferase mediated dUTP nick end labeling (TUNEL).

\subsection{In Vitro Maturation}

Groups of 45-50 COCs were matured in vitro in $500 \mu \mathrm{L}$ medium covered with mineral oil during $24 \mathrm{~h}$ at $38.5^{\circ} \mathrm{C}$ and $5 \% \mathrm{CO}_{2}, 5 \% \mathrm{O}_{2}$ and $90 \% \mathrm{~N}_{2}$ with maximum humidity. IVM medium consisted of TCM 199 (Gibco, Grand Island, NY, USA) supplemented with 
$1 \mu \mathrm{g} / \mathrm{mL}$ Folltropin- $\mathrm{V}^{\circledR}$ (Bioniche, Belleville, ON, Canada) $(v / v), 5 \mathrm{UI} / \mathrm{mL}$ equine chorionic gonadotropin (Biogón ${ }^{\circledR}$ Plus, Biogénesis Bagó, Provincia de Buenos Aires, Argentina) $(v / v)$, $10 \%$ fetal bovine serum (Gibco) $(v / v), 5 \mu \mathrm{g} / \mathrm{mL}$ gentamicin $(v / v)$ and $0.2 \mathrm{mM}$ sodium pyruvate $(w / v)$. For $\alpha$-tocopherol treatment groups, IVM medium was supplemented with different $\alpha$-tocopherol (Sigma, 258024) concentrations (50, 100 and $200 \mu \mathrm{M})$. Antioxidant was first dissolved in absolute ethanol to obtain the stock solution of $0.1,0.2$ and $0.4 \mathrm{M}$ concentration, stored in the dark at $4{ }^{\circ} \mathrm{C}$, and diluted in maturation media to a final concentration of 50, 100 and $200 \mu \mathrm{M} \alpha$-tocopherol, respectively, in $0.05 \%(v / v)$ ethanol, and prepared $4 \mathrm{~h}$ before culture.

\subsection{Parthenogenetic Activation}

After IVM for $24 \mathrm{~h}$, COCs were washed three times in holding medium (114 mM sodium chloride, $3.2 \mathrm{mM}$ potassium chloride, $0.34 \mathrm{mM}$ sodium biphosphate, $0.5 \mathrm{mM}$ magnesium chloride, $2.0 \mathrm{mM}$ calcium chloride, $2 \mathrm{mM}$ sodium bicarbonate, $10 \mathrm{mM}$ sodium lactate, $0.2 \mathrm{mM}$ sodium pyruvate, $4 \mathrm{mg} / \mathrm{mL}$ BSA fraction $\mathrm{V}$, and $50 \mu \mathrm{g} / \mathrm{mL}$ gentamicin) and then incubated in 3 and $7 \%$ ethanol $(v / v)$ in holding medium at $38^{\circ} \mathrm{C}$ for $7 \mathrm{~min}$. After activation, oocytes were washed three time with the same medium and transferred to $500 \mu \mathrm{L}$ IVF-TL in absence of spermatozoa. Control group was cultured in IVF-TL in the same culture conditions, but in absence of ethanol.

\subsection{Assessment of Meiotic Progression}

Briefly, IVM COCs were denuded of cumulus cells by pipetting in phosphate-buffered saline (PBS) supplemented with $200 \mu \mathrm{g} / \mathrm{mL}$ hyaluronidase for $5 \mathrm{~min}$. Denuded oocytes were then fixed in $2.5 \%$ paraformaldehyde $(v / v)$ in modified phosphate-buffered saline (PBS) for $25 \mathrm{~min}$ and stained with $1 \mu \mathrm{g} / \mathrm{mL}$ Hoechst 33342 for $5 \mathrm{~min}$. These oocytes were placed on a slide and immediately observed under a fluorescence microscope Nikon Eclipse 50i equipped with a UV excitation filter at $330-385 \mathrm{~nm}$ and an emission filter at $420 \mathrm{~nm}$. Oocytes were classified as mature (oocytes in metaphase II + polar body), immature (germinal vesicle, metaphase I, anaphase I-telophase I), and degenerated (diffuse or degraded chromatin) [28].

\subsection{In Vitro Fertilization}

Matured COCs were washed twice in in vitro fertilization medium (TL-IVF) containing $10 \mu \mathrm{g} / \mathrm{mL}$ heparin $(v / v), 10 \mu \mathrm{M}$ hypotaurine $(v / v)$ and placed in 4-well culture dishes. Sperm cells were selected with BoviPure density gradient (Nidacon International AB, Mölndal, Sweden) by centrifugation at $300 \times g$ during $10 \mathrm{~min}$. IVF was performed by incubating COCs with $1 \times 10^{6}$ spermatozoa $/ \mathrm{mL}$ in $500 \mu \mathrm{L}$ TL-IVF medium for $22 \mathrm{~h}$ at $38.5{ }^{\circ} \mathrm{C}$ and $5 \% \mathrm{CO}_{2}, 5 \% \mathrm{O}_{2}, 90 \% \mathrm{~N}_{2}$ with maximum humidity.

\subsection{Assessment of Pronucleus Formation}

After $22 \mathrm{~h}$ in IVF-TL, COCs were denuded of cumulus cells, fixed, stained, and evaluated as in previous sections. In experiment 1 , oocytes were classified according to the stage: one or two pronuclei (PN), telophase II, metaphase II or degenerated; while in experiment 2, presumptive zygotes with two PN were considered as having normal fertilization, those with three PN as polyspermic, those with one PN as asynchronous, and those without PN as unfertilized. Total fertilization rate was considered when the oocyte had one, two or more PN.

\subsection{In Vitro Culture}

At $22 \mathrm{~h}$ of coculture, COCs and presumptive zygotes were totally denuded of cumulus cells by pipetting in holding medium and washed twice in modified culture synthetic oviduct fluid (mSOF) [29] containing amino acids, citrate, myoinositol, $5 \mathrm{~g} / \mathrm{L}(w / v)$ BSA and $0.5 \%$ FCS $(v / v)$. Presumptive zygotes were placed in groups between 20 to 25 in mSOF and overlaid with mineral oil at $38.5{ }^{\circ} \mathrm{C}$ and $5 \% \mathrm{CO}_{2}, 5 \% \mathrm{O}_{2}, 90 \% \mathrm{~N}_{2}$ with maximum 
humidity for 9 days. Culture media were replaced with fresh medium (replacement 50\%) at 72,120 and $168 \mathrm{~h}$ of culture. Cleavage, blastocyst rate, and total blastocyst rate was measured on day 3, 7 and 9 of culture, respectively.

\subsection{Cell Counting in Parthenogenetic Blastocysts}

Blastocysts on day 9 were fixed and stained with $1 \mu \mathrm{g} / \mathrm{mL}$ Hoechst 33,342 at $38.5^{\circ} \mathrm{C}$ for $10 \mathrm{~min}$, washed twice in PBS and mounted on slides. They were observed under a fluorescent microscope, and the total number of nuclei for every blastocyst was counted. Stained blastocysts were photographed, and images were evaluated using ImageJ software.

\subsection{Assessment of Total Cell Number and DNA Fragmentation}

TUNEL assay was performed as previously described [8]. Hatched and expanded blastocysts were fixed with $2.5 \%$ paraformaldehyde in PBS for $1 \mathrm{~h}$ at room temperature, washed in PBS and permeabilized in $0.5 \%(v / v)$ Triton X-100 in PBS for 40 min at $4{ }^{\circ} \mathrm{C}$, and washed two times in PBS. Samples were incubated in TUNEL reaction mixture (fluorescein isothiocyanate-conjugated dUTP and terminal deoxynucleotidyl transferase) at $37^{\circ} \mathrm{C}$ for $1 \mathrm{~h}$. TUNEL-stained blastocysts were washed with PBS and incubated in PBS containing $10 \mu \mathrm{g} / \mathrm{mL}$ Hoechst 33342 for $10 \mathrm{~min}$. Blastocysts were washed and mounted onto a glass slide. Negative controls were prepared by omission of terminal deoxynucleotidyl transferase in the reaction mixture, and at the same time positive controls were prepared by pretreatment with $1 \mathrm{mg} / \mathrm{mL}$ DNase I (Roche Diagnostics, Basel, Switzerland) in $5 \mu \mathrm{L}$ of Tris- $\mathrm{HCl}$ buffer, $1 \mu \mathrm{L}$ of DNase, and $30 \mu \mathrm{L}$ of $\mathrm{H}_{2} \mathrm{O}$ for $45 \mathrm{~min}$ at $37^{\circ} \mathrm{C}$. All samples were analyzed in a Nikon Eclipse 50i fluorescence microscope with filters for FITC (emission 520 and excitation 460-490) and Hoechst (emission 420 and excitation 330-385). TUNELpositive blastomeres were fluorescently labeled green, indicating apoptosis. Blue (Hoechst) fluorescence indicated the presence of nuclei. Blastomeres were counted and analyzed using the open-source software Fiji/ImageJ. Apoptotic index was determined by dividing the total number of TUNEL positive blastomeres by the total number of blastomeres.

\subsection{Gene Expression}

Three replicates of expanded blastocysts treated with 0, 0.5\% ethanol, 50, 100 and $200 \mu \mathrm{M} \alpha$-Tocopherol were analyzed. All blastocysts were washed in $\mathrm{Ca}^{2+}$ - and $\mathrm{Mg}^{2+}$-free PBS, and placed in $20 \mu \mathrm{L}$ of RNA later ${ }^{\mathrm{TM}}$ Solution (Invitrogen, Waltham, MA, USA; Thermo Fisher Scientific, Waltham, MA, USA), snap-frozen in liquid nitrogen, and stored at $-20{ }^{\circ} \mathrm{C}$ until gene expression analysis. Quick-RNA Microprep Kit (Zymo Research, California, USA) was used, for blastocyst RNA isolation followed by DNAse treatment using DNAFree kit (Gibco), according to the manufacturer's instructions. Total RNA concentration was determined by measuring the absorbance at $260 \mathrm{~nm}$ and its purity was evaluated at an absorption ratio of $260 / 280$. For each sample, cDNA was synthesized by reverse transcription using a SuperScript III transcriptase (Thermo Fisher Scientific, Waltham, MA, USA) with random primers and $500 \mathrm{ng}$ of total RNA as a template.

The expression of target genes was quantified using real-time PCR (qPCR). Primer sequences and the expected product lengths for genes IFNT2, HSPA1A, CAT, SOD2, BCL2 and $B A X$, and the endogenous control GAPDH are presented in Table 1. The reactions used for real-time PCR were prepared using $7.5 \mu \mathrm{L}$ of SYBRGreen master mix (Thermo Fisher Scientific, Waltham, MA, USA), equimolar quantities of the forward and reverse primers $(10 \mu \mathrm{M}), 2 \mu \mathrm{L}$ of cDNA sample and $4.5 \mu \mathrm{L}$ of RNAse/DNAse-free water at a final volume of $15 \mu \mathrm{L}$. Samples were amplified in duplicate in a Rotor-Gene 6000 72-disc rotor (Corbett Life Sciences, Sydney Australia). Standard amplification conditions were: $5 \mathrm{~min}$ at $95^{\circ} \mathrm{C}$ and 40 cycles of $15 \mathrm{~s}$ at $95^{\circ} \mathrm{C}, 40 \mathrm{~s}$ at $60^{\circ} \mathrm{C}$ and $20 \mathrm{~s}$ at $72{ }^{\circ} \mathrm{C}$. At the end of each run, melting curves were analyzed to ensure that the desired amplicon was detected, discarding contaminating DNA or primer dimers. A no-template control (NTC negative control) was used to corroborate the absence of contaminating DNA. The relative quantification of gene expression changes was recorded after normalizing for GAPDH gene expression 
computed using the $2^{-\Delta \Delta C T}$ method [30] in which CT value from a pool of all samples served as calibrator.

Table 1. Details of primers used for qPCR.

\begin{tabular}{|c|c|c|c|c|}
\hline Gene Name & Gene Symbol & $\begin{array}{c}\text { Primer } \\
\text { Sequence }\left(5^{\prime}-3^{\prime}\right)\end{array}$ & Fragment Size (bp) & $\begin{array}{c}\text { GenBank } \\
\text { Accession No. }\end{array}$ \\
\hline Interferon tau & IFNT2 & $\begin{array}{c}\text { F: TCTGAGGACCA- } \\
\text { CATGCTAGG } \\
\text { R: GATCCTTCTG- } \\
\text { GAGCTGGTTG }\end{array}$ & 145 & NM_001015511.3 \\
\hline Heat shock protein 70 & HSPA1A & $\begin{array}{l}\text { F: CTTCAACATGAA- } \\
\text { GAGCGCCG } \\
\text { R: TGATGGGGTTACA- } \\
\text { CACCTGC }\end{array}$ & 182 & NM_203322.3 \\
\hline $\begin{array}{c}\text { Manganese } \\
\text { superoxide dismutase }\end{array}$ & SOD2 & $\begin{array}{l}\text { F: CCCATGAAGC- } \\
\text { CTTTCTAATCCTG } \\
\text { R: TTCAGAGGCGC- } \\
\text { TACTATTTCCTTC }\end{array}$ & 307 & NM_201527.2 \\
\hline Catalase & $C A T$ & $\begin{array}{c}\text { F: GTTCGCTTCTC- } \\
\text { CACTGTT } \\
\text { R: GGC- } \\
\text { CATAGTCAGGATCTT }\end{array}$ & 454 & NM_001035386.2 \\
\hline Bcl-2-associated X protein & $B A X$ & $\begin{array}{c}\text { F: TTTGCTTCAGG } \\
\text { GTTTCATCCA } \\
\text { R: CCGATGCGCTTCA- } \\
\text { GACACT }\end{array}$ & 126 & NM_173894.1 \\
\hline B-cell lymphoma 2 & $B C L 2$ & $\begin{array}{c}\text { F: GAGTCGGATCG } \\
\text { CAACTTGGA } \\
\text { R: CTCTCGGCTGCTG- } \\
\text { CATTGT }\end{array}$ & 120 & NM_001077486.2 \\
\hline $\begin{array}{c}\text { Glyceraldehyde } \\
\text { 3-phosphate dehydrogenase }\end{array}$ & GAPDH & $\begin{array}{c}\text { F: GATTGTC } \\
\text { AGCAATGCCTCCT } \\
\text { R: GGTCATAAGTCC- } \\
\text { CTCCACGA }\end{array}$ & 94 & NM_001034034.2 \\
\hline
\end{tabular}

Abbreviations: F: forward; R: reverse.

\subsection{Statistical Analysis}

Normality was checked with the Kolmogorov-Smirnov test, and homogeneity of variance was examined by Levene's test. The Wilcoxon rank-sum test was performed for the data without normal distribution. Data were analyzed by one-way analysis of variance (ANOVA) with the Tukey test using SAS software (version 9.2; SAS Inst. Inc.; Cary, NC, USA). Results were expressed as the mean \pm standard error of mean (s.e.m.). Differences between means were considered significant when $p<0.05$.

\section{Results}

Table 2 shows environmental data recovered during the period of study. The average $\mathrm{THI}$ in the summer was around 72, indicating an alert level for cows under conditions of acute heat stress [31].

\subsection{Experiment 1}

No significant differences were found in the proportion of mature $(72.65 \pm 0.65$ and $72.14 \pm 1.54 ; p=0.77)$, immature (19.8 \pm 2.7 and $19.82 \pm 2.2 ; p=0.9)$ and degenerate $(7.56 \pm 3.21$ and $8 \pm 2.28 ; p=0.9)$ oocytes IVM for $24 \mathrm{~h}$ in presence $(0.05 \%)$ or absence of ethanol, respectively. After $22 \mathrm{~h}$ of culture in absence of spermatozoa, oocytes from control and ethanol at $0.05 \%$ groups showed a clear delay in the formation of pronuclei (Table 3 ). 
Cleavage rate and parthenogenetic blastocysts rate were also significantly lower in both groups (Figure 1A). Representative digital images of parthenogenetic blastocysts stained with Hoechst 33324 are shown in Figure 1B. Parthenogenetic blastocysts total cell number did not differ significantly ( $p=0.086$ ) between control, $0.05 \%, 3$ and $7 \%$ ethanol group $(62 \pm 3.0,63 \pm 2.67,77.66 \pm 5.58$ and $75.77 \pm 3.3$, respectively).

Table 2. Maximum, minimum and average ( \pm s.e.m) values for temperature $\left({ }^{\circ} \mathrm{C}\right)$, relative humidity $(\%)$ and temperaturehumidity index (THI) recovered between 21 December 2020 to 9 March 2021 reported in the north of Uruguay.

\begin{tabular}{cccc}
\hline & Temperature $\left({ }^{\circ} \mathrm{C}\right)$ & Relative Humidity (\%) & THI \\
\hline Maximal & $25-29.8$ & $87-94$ & $75.78-83.94$ \\
Minimal & $19.7-21.8$ & $44-71$ & $64.81-67.88$ \\
Average & $23.31 \pm 1.22$ & $70.38 \pm 5.05$ & $71.31 \pm 1.5$ \\
\hline
\end{tabular}

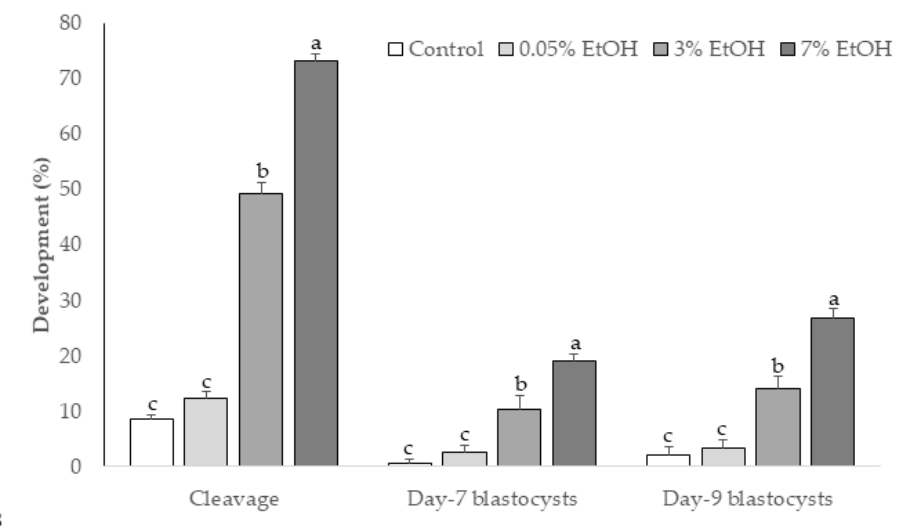

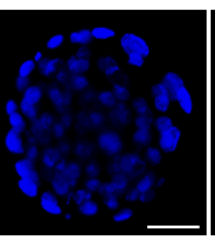

Control

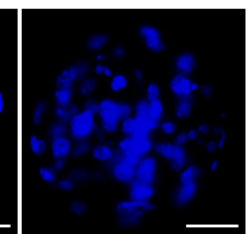

$0.05 \% \mathrm{EtOH}$

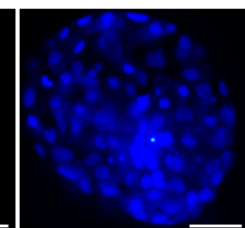

$3 \% \mathrm{EtOH}$

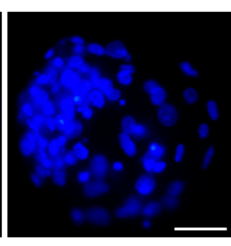

$7 \% \mathrm{EtOH}$

Figure 1. Effect of ethanol concentration on bovine oocyte parthenogenetic activation. (A) Percentage (\% \pm s.e.m) of cleavage (day 3), blastocysts' development (day 7 and 9), and (B) blastomere nuclei stained with Hoechst in parthenogenic embryos derived from bovine oocytes matured without (control) or with $0.05 \%$ ethanol for $24 \mathrm{~h}$ or activated with $3 \%$ or $7 \%$ ethanol for $7 \mathrm{~min}$. The white bar represents the $50 \mu \mathrm{m}$ mark. Different letters above each bar indicate statistical significance $(p<0.05)$.

\subsection{Experiment 2}

The percentage of oocytes reaching metaphase II and presumptive zygotes with normal fertilization were similar in all treatments (Table 4 ). The proportion of cleaved embryos derived from COCs supplemented with $\alpha-50$ and $\alpha-100$ was significantly higher than that in the control group $(p<0.05)$. The highest blastocysts rate on day 9 was obtained in the $\alpha-100$ group, but it only differed significantly from the $\alpha-200$ group. Hatched blastocyst rates were similar in all groups (Figure 2).

Although blastocyst total cell numbers did not differ among treatments $(p=0.825)$, however, the addition of $100 \mu \mathrm{M}$ of $\alpha$-tocopherol during IVM reduced the proportion of TUNEL-positive blastomeres (Figure 3B). A higher mRNA abundance was observed for SOD2 $(p<0.05)$ in blastocysts in the $\alpha-100$ group, compared to the other treatment groups, while no differences were detected in the expression levels of IFNT2, HSPA1A, CAT, BCL2 and $B A X$ (Figure 4) among groups. 
Table 3. Percentages ( $\% \pm$ s.e.m.) of pronucleus formation, telophase II, metaphase II + polar body, immature (germinal vesicle, metaphase I, anaphase I, telophase I) and degenerate in bovine oocytes cultured for $22 \mathrm{~h}$ (IVF-TL) in absence of spermatozoa and after of in vitro maturation without (control) or with ethanol at $0.05 \%$ for $24 \mathrm{~h}$ or activated with ethanol at $3 \%$ or $7 \%$ for $7 \mathrm{~min}$.

\begin{tabular}{|c|c|c|c|c|c|}
\hline & $\begin{array}{c}\text { Control } \\
(\% \pm \text { s.e.m.) }\end{array}$ & $\begin{array}{l}0.05 \% \text { EtOH } \\
\text { (\% } \pm \text { s.e.m.) }\end{array}$ & $\begin{array}{c}3 \% \text { EtOH } \\
(\% \pm \text { s.e.m.) }\end{array}$ & $\begin{array}{c}7 \% \text { EtOH } \\
(\% \pm \text { s.e.m.) }\end{array}$ & $p$-Value \\
\hline \multicolumn{6}{|l|}{ Stages of nucleus } \\
\hline 2 Pronucleus & 0 & 0 & $2.08 \pm 2.0$ & $5.00 \pm 2.23$ & 0.098 \\
\hline 1 Pronuclei & $7.91 \pm 2.75^{b}$ & $7.69 \pm 2.9^{b}$ & $19.37 \pm 3.5^{\mathrm{a}}$ & $25.09 \pm 2.25^{\mathrm{a}}$ & 0.006 \\
\hline Telophase II & $4.16 \pm 2.84$ & $4.44 \pm 2.93$ & $9.12 \pm 4.28$ & $3.33 \pm 3.0$ & 0.62 \\
\hline Metaphase II + polar body & $65.42 \pm 2.00$ & $58.73 \pm 2.42$ & $52.62 \pm 6.32$ & $50.18 \pm 3.68$ & 0.062 \\
\hline Immature & $10.27 \pm 3.34$ & $11.99 \pm 3.91$ & $4.16 \pm 2.63$ & $7.26 \pm 2.32$ & 0.32 \\
\hline Degenerated & $12.21 \pm 2.97$ & $18.1 \pm 1.07$ & $15.96 \pm 4.05$ & $9.12 \pm 3.42$ & 0.21 \\
\hline Total oocytes evaluated & 54 & 53 & 48 & 53 & \\
\hline
\end{tabular}

Different letters in the rows indicate statistical significance $(p<0.05)$.

Table 4. Percentages ( $\% \pm$ s.e.m.) of mature (metaphase II, immature and degenerate) and fertilized (total, normal, polyspermic, asynchronous and not fertilized) bovine oocytes collected in summer and in vitro matured in absence (control and $0.05 \%$ ethanol) or presence of $\alpha$-tocopherol at $50(\alpha-50), 100(\alpha-100)$ and $200(\alpha-200) \mu \mathrm{M}$.

\begin{tabular}{|c|c|c|c|c|c|c|}
\hline & $\begin{array}{c}\text { Control } \\
\text { (\% } \% \text { s.e.m.) }\end{array}$ & $\begin{array}{c}\text { Ethanol } \\
(\% \pm \text { s.e.m.) }\end{array}$ & $\begin{array}{c}\alpha-50 \\
(\% \pm \text { s.e.m.) }\end{array}$ & $\begin{array}{c}\alpha-100 \\
\text { (\% } \pm \text { s.e.m.) }\end{array}$ & $\begin{array}{c}\alpha-200 \\
(\% \pm \text { s.e.m. })\end{array}$ & $p$-Value \\
\hline \multicolumn{7}{|l|}{ Nuclear maturation } \\
\hline Metaphase II + polar body & $71.66 \pm 1.9$ & $73.35 \pm 3.17$ & $71.7 \pm 1.08$ & $76.49 \pm 1.89$ & $76.54 \pm 1.98$ & 0.14 \\
\hline Immature & $17.8 \pm 2.32$ & $20.28 \pm 1.5$ & $20.89 \pm 2.74$ & $16.66 \pm 0.53$ & $18.54 \pm 2.01$ & 0.63 \\
\hline Degenerated & $9.58 \pm 2.42$ & $7.24 \pm 2.4$ & $7.46 \pm 2.1$ & $6.91 \pm 1.96$ & $5.08 \pm 2.48$ & 0.27 \\
\hline Total oocytes evaluated & 73 & 69 & 67 & 66 & 59 & \\
\hline \multicolumn{7}{|l|}{ Fertilization rate } \\
\hline Total fertilized & $78.55 \pm 1.81$ & $75.89 \pm 1.74$ & $77.14 \pm 2.79$ & $80.58 \pm 14$ & $73.74 \pm 2.77$ & 0.25 \\
\hline Normal & $60.1 \pm 1.79$ & $58.1 \pm 2.26$ & $59 \pm 2.8$ & $65.51 \pm 1.71$ & $60.12 \pm 3.9$ & 0.25 \\
\hline Polyspermic & $5.92 \pm 2.48$ & $4.62 \pm 2.34$ & $5.27 \pm 2$ & 0 & $1.78 \pm 1.78$ & 0.2 \\
\hline Asyncronic & $18.45 \pm 1.76$ & $17.78 \pm 1.73$ & $18.36 \pm 1.58$ & $15.06 \pm 1.32$ & $14.62 \pm 3.86$ & 0.5 \\
\hline Unfertilized & $21.43 \pm 1.81$ & $24.09 \pm 1.74$ & $22.84 \pm 2.79$ & $19.4 \pm 1.4$ & $26.24 \pm 2.77$ & 0.26 \\
\hline Total oocytes evaluated & 71 & 73 & 70 & 66 & 73 & \\
\hline
\end{tabular}

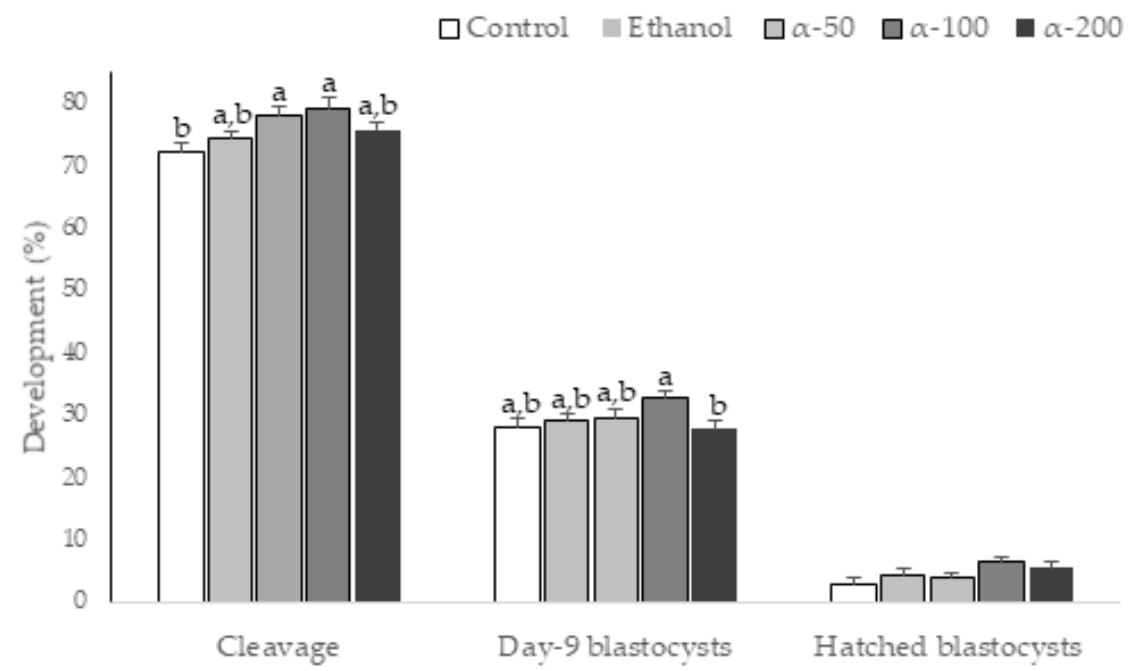

Figure 2. Effect of different $\alpha$-tocopherol concentrations during bovine oocyte in vitro maturation on cleavage, blastocyst and hatching rates. Control: $0 \%$ ethanol and 0,0 $\alpha$-tocopherol; Ethanol: $0.05 \%$ ethanol and 0,0 $\alpha$-tocopherol; $\alpha$-50: $50 \mu \mathrm{M} \alpha$-tocopherol; $\alpha$-100: $100 \mu \mathrm{M} \alpha$-tocopherol; $\alpha$-200: $200 \mu \mathrm{M}$ $\alpha$-tocopherol. Different letters above each bar represent significant difference $(p<0.05)$. 
A
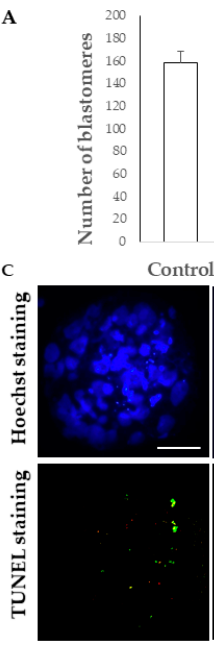

Control
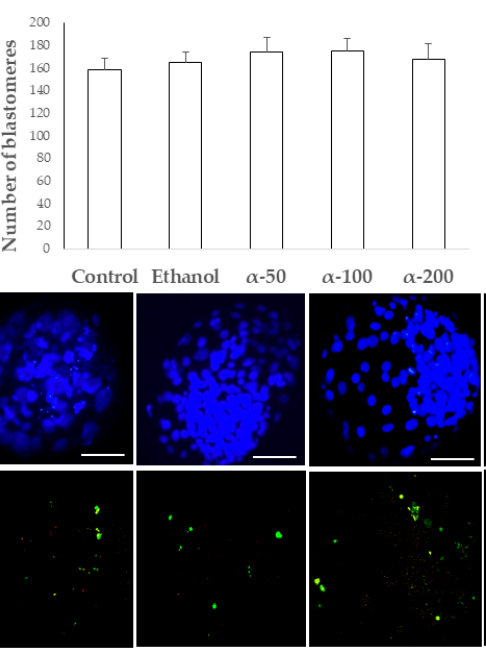

$\alpha-50$

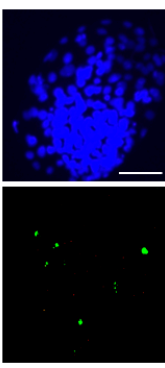

Ethanol
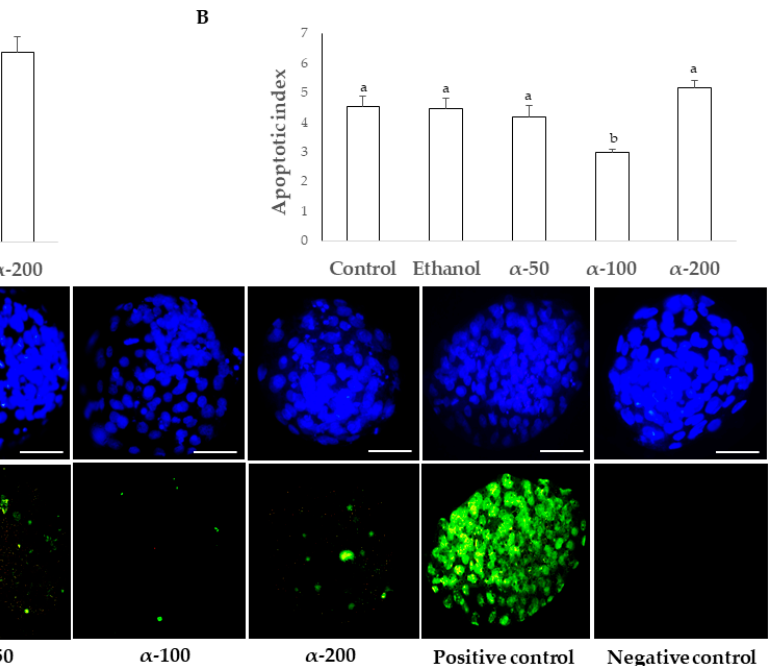

Figure 3. Effect of different $\alpha$-tocopherol concentrations during bovine oocyte in vitro maturation on (A) total cell number, and (B) blastocyst apoptotic index. (C) Representative digital images of Hoechst and TUNEL staining of day 9 blastocysts derived from bovine oocytes collected during summer and in vitro matured in absence (control and $0.05 \%$ ethanol) or presence of $\alpha$-tocopherol at $50(\alpha-50), 100(\alpha-100), 200(\alpha-200) \mu \mathrm{M}$, and positive and negative TUNEL assay controls. The white bar represents the $50 \mu \mathrm{m}$ mark. Different letters above each bar represent significant differences $(p<0.05)$.
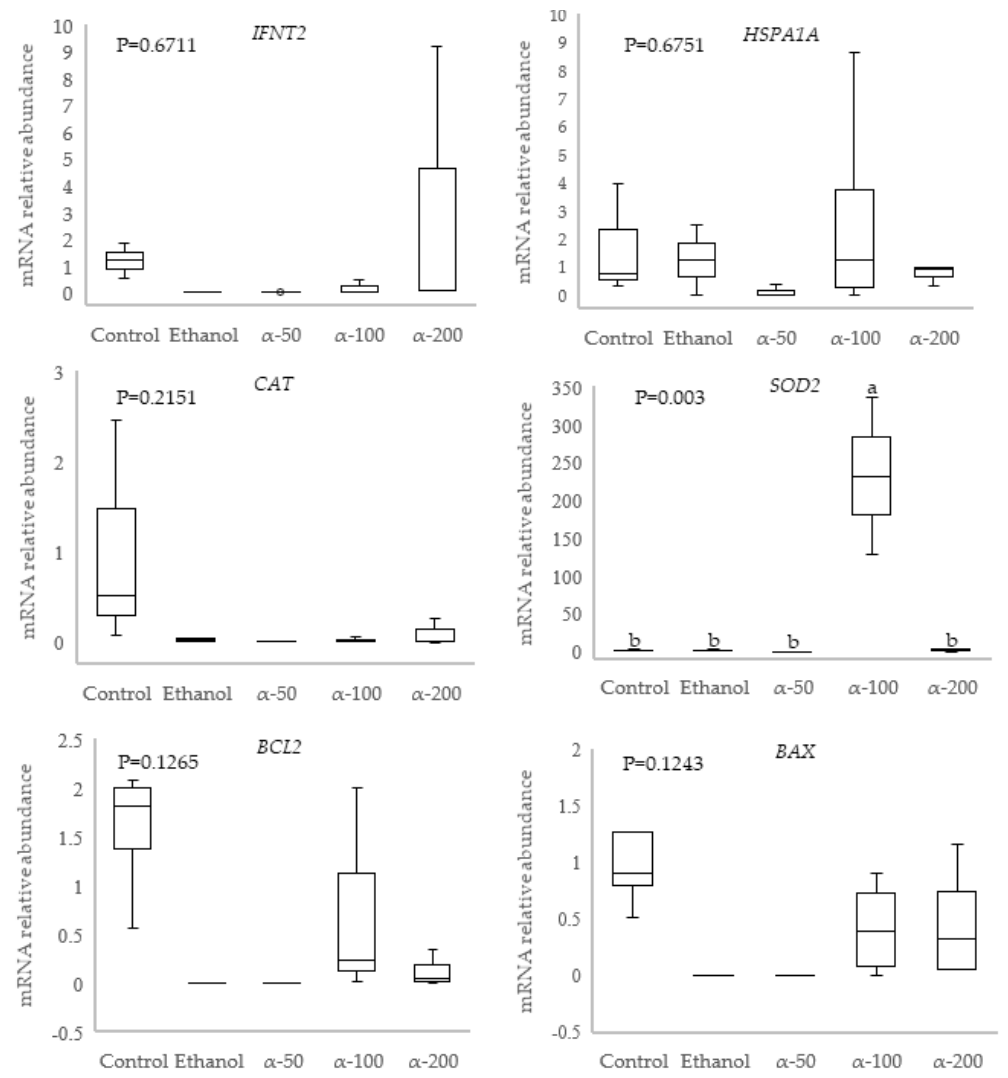

Figure 4. Effect of different concentrations of $\alpha$-tocopherol during in vitro maturation of summer bovine oocytes on relative mRNA abundance of genes in expanded blastocysts of day 9 of in vitro culture. Interferon tau (IFNT2); Heat shock protein 70 (HSPA1A); Catalase (CAT); Manganese superoxide dismutase (SOD2); Bcl-2-associated X protein (BAX); B-cell lymphoma 2 (BCL2). Control: $0 \%$ ethanol and 0,0 $\alpha$-tocopherol; Ethanol: $0.05 \%$ ethanol and 0,0 $\alpha$-tocopherol; $\alpha$-50: $50 \mu \mathrm{M} \alpha$ tocopherol; $\alpha$-100: $100 \mu \mathrm{M} \alpha$-tocopherol; $\alpha$-200: $200 \mu \mathrm{M} \alpha$-tocopherol. Different letters above each box represent statistically significant difference $(p<0.05)$. 


\section{Discussion}

The results of the present study demonstrate for the first time that the use of ethanol at $0.05 \%(v / v)$ under $5 \% \mathrm{O}_{2}$ during IVM does not promote parthenogenesis. The addition of $\alpha$-tocopherol during IVM of summer-collected bovine oocytes affects blastocyst quality and yield in a dose-dependent manner. Supplementation of IVM medium with $100 \mu \mathrm{M} \alpha$-tocopherol reduced the apoptotic index increased blastocysts quality and induced overexpression of SOD2 in expanded blastocysts.

The delay in the proportion of pronuclear formation and low cleavage and blastocyst rates in both control and $0.05 \%$ ethanol groups indicate that our culture conditions do not promote bovine oocyte activation, meiotic resumption, or parthenogenetic development. In both groups, cleavage ( $8-12 \%)$ and blastocyst $(1.5-2.8 \%)$ rates were similar to those reported by Méo et al. [32,33]. Spontaneous oocyte activation is influenced by prolonged culture times, $26 \mathrm{~h}$ for IVM and $44 \mathrm{~h}$ for IVM-IVF combined [23,34], and can indicate low oocyte quality or incomplete cytoplasmatic maturation [28]. Previous studies have demonstrated that summer-obtained oocytes, as was the case for oocytes in our study, are of lower quality than those collected during winter $[9,10]$. The levels of parthenogenetic activation in our control and ethanol groups could be attributed to spontaneous activation due to low oocyte quality.

Our results suggest that a single ethanol treatment ( 3 and $7 \%$ ethanol $v / v$ ) for a few minutes was effective for parthenogenetic activation. Recent studies have reported similar cleavage and blastocyst rates after bovine oocyte parthenogenetic activation with $5 \mu \mathrm{M}$ ionomycin and $2 \mathrm{mM}$ 6-dimethylaminopurine [35,36]. The combination of $5 \mu \mathrm{M}$ ionomycin, $7 \%$ ethanol $(v / v)$, and $50 \mu \mathrm{M}$ roscovitine improved pronucleus formation rates in parthenogenetic embryos, while the highest blastocyst yields were observed in the ionomycin and 6-dimethylaminopurine treatment [24]. However, these protocols are long, involve several steps, and are difficult to reproduce. In addition, we isolated total RNA from parthenogenetic blastocysts, during preliminary experiments, and used it for successful qPCR standardization, indicating that parthenogenetic blastocysts had an active transcription machinery. Considering that artificial activation of bovine oocytes is a critical step for reproductive biotechnologies such as Intracytoplasmic Sperm Injection or Somatic Cell Nuclear Transfer [24], we propose this methodology for successful parthenogenetic activation of bovine oocytes. It could potentially be applied in other species as study material or stem cell source.

In the second experiment, the proportion of matured, normally fertilized oocytes and blastocyst cell numbers were not affected by the addition of $\alpha$-tocopherol during IVM. Several studies show that the addition of $\alpha$-tocopherol during maturation does not directly influence meiotic progression and IVF rate in cow [37], buffalo [38], sheep [39], pig $[17,21,40]$, or rabbit [20]. Our results coincide with a previous study that did not observe any increase in total blastomere number in sheep blastocysts, after media supplementation with $\alpha$-tocopherol during IVC [18]. Nevertheless, $\alpha$-tocopherol improved the oocyte intrinsic competence, which can be assessed through embryonic development $[20,41]$ as demonstrated in this study.

The addition of $100 \mu \mathrm{M} \alpha$-tocopherol during IVM of bovine oocytes increased blastocyst rate, decreased apoptotic index and increased the expression of SOD2 in 9-day blastocysts. These changes were not observed in groups supplemented with a lower or higher $\alpha$-tocopherol concentration. However, the effects of this treatment were not associated with changes in the expression of CAT, HSPA1A, BAX, BCL2 or IFNT2. SOD2 is a mitochondrial antioxidant enzyme that converts the anion superoxide $\left(\mathrm{O}^{2-}\right)$ into $\mathrm{H}_{2} \mathrm{O}_{2}$ [42]. An overexpression of $S O D 2$ [43], but not of $C A T$, has been associated with higher embryo quality [44]. In fact, SOD2 expression was downregulated in vitrified-thawed blastocysts [45] or blastocysts derived from heat-shock oocytes, which were cultured at $41{ }^{\circ} \mathrm{C}$ during IVM [22]. Recent studies revealed that an increase in SOD2 expression, as shown in the present study, can be attributed to an effect of $\alpha$-tocopherol on the expression of antioxidant genes [46]. 
The study conducted by Borcari et al. [46] showed that diet $\alpha$-tocopherol increased the expression of antioxidant genes and decreased the expression of prooxidant genes. $\alpha$-tocopherol influenced epigenetic machinery and downregulated DNA methylation in specific genes in mice (revised by Chen et al. [47]). Our results suggest that the beneficial effect of $\alpha$-tocopherol is dose-dependent, which agrees with a recent study showing that $\alpha$-tocopherol exhibits positive effects on oxidative stress and epigenetic regulation involved in DNA repair in a dose-dependent manner [48]. In mice, vitamin E supplementation reduced DNA damage and affected Dnmt1 and MLH1 gene expression and methylation [49]. We could hypothesize that the addition of $100 \mu \mathrm{M} \alpha$-tocopherol to the IVM medium improved the developmental potential and quality of blastocysts stimulating the expression of SOD2. However, the use of only two $\alpha$-tocopherol concentrations in this study limited our understanding of the dose-dependent effect of $\alpha$-tocopherol on oocyte maturation and competence.

In conclusion, $0.05 \%(v / v)$ ethanol does not induce parthenogenetic activation of bovine oocytes, therefore, at this concentration, ethanol can be used as a safe vehicle for hydrophobic molecules in embryo production systems. In contrast, a single $>3 \%(v / v)$ ethanol treatment for $7 \mathrm{~min}$ is an effective procedure for parthenogenetic activation. The addition of $100 \mu \mathrm{M} \alpha$-tocopherol diluted in $0.05 \%$ ethanol during IVM improves oocyte competence leading to an increase in blastocyst production and higher embryo quality, without the risk of inducing parthenogenetic activation.

Author Contributions: Conceptualization, F.B., V.d.B., N.R.-O. and C.V.; methodology, F.B., B.G. and V.d.B.; formal analysis, F.B.; investigation, F.B., N.R.-O. and C.V.; data curation, F.B. and N.R.-O.; writing-original draft preparation, F.B.; writing-review and editing, N.R.-O. and C.V.; visualization, F.B.; funding acquisition, F.B., N.R.-O. and C.V. All authors have read and agreed to the published version of the manuscript.

Funding: This research received no external funding.

Institutional Review Board Statement: Not applicable.

Informed Consent Statement: Not applicable.

Data Availability Statement: In the results section the study presents all data generated.

Acknowledgments: The authors are grateful to PEDECIBA Biología for their support for the publication of this study, and to slaughterhouse Tacuarembó of Marfrig group S.A. for providing the ovaries.

Conflicts of Interest: The authors declare no conflict of interest.

\section{References}

1. Giro, A.; Carlos, A.; Bernardi, D.C.; Barioni, W.; Prudêncio, A.; Botta, D.; Romanello, N.; Barreto, N.; Rossetto, A. Application of microchip and infrared thermography for monitoring body temperature of beef cattle kept on pasture. J. Therm. Biol. 2019, 84, 121-128. [CrossRef] [PubMed]

2. Hansen, P.J. Effects of heat stress on mammalian reproduction. Philos. Trans. R. Soc. B Biol. Sci. 2009, 364, 3341-3350. [CrossRef]

3. Roth, Z. Reproductive physiology and endocrinology responses of cows exposed to environmental heat stress-Experiences from the past and lessons for the present. Theriogenology 2020, 155, 150-156. [CrossRef] [PubMed]

4. Stamperna, K.; Giannoulis, T.; Nanas, I.; Dadouli, K.; Moutou, K.; Amiridis, G.S. Short term temperature elevation during IVM affects embryo yield and alters gene expression pattern in oocytes, cumulus cells and blastocysts in cattle. Theriogenology 2020, 156, 36-45. [CrossRef] [PubMed]

5. De Rensis, F.; Scaramuzzi, R.J. Heat stress and seasonal effects on reproduction in the dairy cow-A review. Theriogenology 2003, 60, 1139-1151. [CrossRef]

6. Wolfenson, D.; Roth, Z.; Meidan, R. Impaired reproduction in heat-stressed cattle: Basic and applied aspects. Anim. Reprod. Sci. 2000, 60-61, 535-547. [CrossRef]

7. Morrell, J.M. Theriogenology Heat stress and bull fertility. Theriogenology 2020, 153, 62-67. [CrossRef] [PubMed]

8. Rodrigues, T.A.; Ispada, J.; Risolia, P.H.B.; Rodrigues, M.T.; Lima, R.S.; Assumpção, M.E.O.A.; Visintin, J.A.; Paula-Lopes, F.F. Thermoprotective effect of insulin-like growth factor 1 on in vitro matured bovine oocyte exposed to heat shock. Theriogenology 2016, 86, 2028-2039. [CrossRef] [PubMed]

9. Al-Katanani, Y.M.; Paula-Lopes, F.F.; Hansen, P.J. Effect of season and exposure to heat stress on oocyte competence in Holstein cows. J. Dairy Sci. 2002, 85, 390-396. [CrossRef] 
10. Rocha, A.; Randel, R.D.; Broussard, J.R.; Lim, J.M.; Blair, R.M.; Roussel, J.D.; Godke, R.A.; Hansel, W. High environmental temperature and humidity decrease oocyte quality in Bos taurus but not in Bos indicus cows. Theriogenology 1998, 49, 657-665. [CrossRef]

11. Roth, Z.; Arav, A.; Bor, A.; Zeron, Y.; Braw-Tal, R.; Wolfenson, D. Improvement of quality of oocytes collected in the autumn by enhanced removal of impaired follicles from previously heat-stressed cows. Reproduction 2001, 122, 737-744. [CrossRef]

12. Roth, Z. Heat stress reduces maturation and developmental capacity in bovine oocytes. Reprod. Fertil. Dev. 2021, 33, 66-75. [CrossRef]

13. Ferreira, R.M.; Ayres, H.; Chiaratti, M.R.; Ferraz, M.L.; Araújo, A.B.; Rodrigues, C.A.; Watanabe, Y.F.; Vireque, A.A.; Joaquim, D.C.; Smith, L.C.; et al. The low fertility of repeat-breeder cows during summer heat stress is related to a low oocyte competence to develop into blastocysts. J. Dairy Sci. 2011, 94, 2383-2392. [CrossRef] [PubMed]

14. Yaacobi-Artzi, S.; Shimoni, C.; Kalo, D.; Hansen, P.J.; Roth, Z. Melatonin slightly alleviates the effect of heat shock on bovine oocytes and resulting blastocysts. Theriogenology 2020, 158, 477-489. [CrossRef]

15. Morado, S.A.; Cetica, P.D.; Beconi, M.T.; Dalvit, G.C. Reactive oxygen species in bovine oocyte maturation In Vitro. Reprod. Fertil. Dev. 2009, 21, 608-614. [CrossRef]

16. Kitagawa, Y.; Suzuki, K.; Yoneda, A.; Watanabe, T. Effects of oxygen concentration and antioxidants on the In Vitro developmental ability, production of reactive oxygen species (ROS), and DNA fragmentation in porcine embryos. Theriogenology 2004, 62, 1186-1197. [CrossRef] [PubMed]

17. Tao, Y.; Chen, H.; Tian, N.N.; Huo, D.T.; Li, G.; Zhang, Y.H.; Liu, Y.; Fang, F.G.; Ding, J.P.; Zhang, X.R. Effects of L-Ascorbic Acid, $\alpha$-Tocopherol and Co-culture on In Vitro Developmental Potential of Porcine Cumulus Cells Free Oocytes. Reprod. Domest. Anim. 2010, 45, 19-25. [CrossRef] [PubMed]

18. Natarajan, R.; Shankar, M.B.; Munuswamy, D. Effect of $\alpha$-tocopherol supplementation on In Vitro maturation of sheep oocytes and In Vitro development of preimplantation sheep embryos to the blastocyst stage. J. Assist. Reprod. Genet. 2010, 27, 483-490. [CrossRef]

19. Olson, S.E.; Seidel, G.E. Culture of In Vitro-Produced Bovine Embryos with Vitamin E Improves Development In Vitro and After Transfer to Recipients 1. Biol. Reprod. 2000, 62, 248-252. [CrossRef]

20. Arias-Álvarez, M.; García-García, R.M.; López-Tello, J.; Rebollar, P.G.; Gutiérrez-Adán, A.; Lorenzo, P.L. $\alpha$-Tocopherol modifies the expression of genes related to oxidative stress and apoptosis during In Vitro maturation and enhances the developmental competence of rabbit oocytes. Reprod. Fertil. Dev. 2018, 30, 1728-1738. [CrossRef]

21. Tao, Y.; Zhou, B.; Xia, G.; Wang, F.; Wu, Z.; Fu, M. Exposure to L-Ascorbic Acid or $\alpha$-Tocopherol Facilitates the Development of Porcine Denuded Oocytes from Metaphase I to Metaphase II and Prevents Cumulus Cells from Fragmentation. Reprod. Domest. Anim. 2004, 39, 52-57. [CrossRef]

22. Amaral, C.S.; Koch, J.; Correa, E.E., Jr.; Bertolin, K.; Mujica, L.K.S.; Fiorenza, M.F.; Rosa, S.G.; Nogueira, C.W.; Comim, F.V.; Portela, V.V.M.; et al. Heat stress on oocyte or zygote compromises embryo development, impairs interferon tau production and increases reactive oxygen species and oxidative stress in bovine embryos produced In Vitro. Mol. Reprod. Dev. 2020, 87, 899-909. [CrossRef] [PubMed]

23. Minamihashi, A.; Watson, A.J.; Watson, P.H.; Church, R.B.; Schultz, G.A. Bovine parthenogenetic blastocysts following In Vitro maturation and oocyte activation with ethanol. Theriogenology 1993, 40, 63-76. [CrossRef]

24. Suvá, M.; Canel, N.G.; Salamone, D.F. Effect of single and combined treatments with MPF or MAPK inhibitors on parthenogenetic haploid activation of bovine oocytes. Reprod. Biol. 2019, 19, 386-393. [CrossRef]

25. Novaes, M.A.S.; Lima, L.F.; Sá, N.A.R.; Ferreira, A.C.A.; Paes, V.M.; Souza, J.F.; Alves, B.G.; Gramosa, N.V.; Torres, C.A.A.; Pukazhenthi, B.; et al. Impact of ethanol and heat stress-dependent effect of ultra-diluted Arnica montana $6 \mathrm{cH}$ on In Vitro embryo production in cattle. Theriogenology 2021, 162, 105-110. [CrossRef] [PubMed]

26. Thom, E.C. The Discomfort Index. Weatherwise 1959, 12, 57-61. [CrossRef]

27. Harvey, A.J. The role of oxygen in ruminant preimplantation embryo development and metabolism. Anim. Reprod. Sci. 2007, 98, 113-128. [CrossRef] [PubMed]

28. Tseng, J.K.; Chen, C.H.; Chou, P.C.; Yeh, S.P.; Ju, J.C. Influences of follicular size on parthenogenetic activation and In Vitro heat shock on the cytoskeleton in cattle oocytes. Reprod. Domest. Anim. 2004, 39, 146-153. [CrossRef]

29. Holm, P.; Booth, P.J.; Schmidt, M.H.; Greve, T.; Callesen, H. High bovine blastocyst development in a static In Vitro production system using SOFaa medium supplemented with sodium citrate and myo-inositol with or without serum-proteins. Theriogenology 1999, 52, 683-700. [CrossRef]

30. Livak, K.J.; Schmittgen, T.D. Analysis of relative gene expression data using real-time quantitative PCR and the $2^{-\Delta \Delta C T}$ method. Methods 2001, 25, 402-408. [CrossRef]

31. Du Preez, J.H.; Giesecke, W.H.; Hattingh, P.J. Heat stress in dairy cattle and other livestock under southern African conditions. I. Temperature-humidity index mean values during the four main seasons. Onderstepoort J. Vet. Res. 1990, 57, 77-87.

32. Méo, S.C.; Yamazaki, W.; Ferreira, C.R.; Perecin, F.; Saraiva, N.Z.; Leal, C.L.V.; Garcia, J.M. Parthenogenetic activation of bovine oocytes using single and combined strontium, ionomycin and 6-dimethylaminopurine treatments. Zygote 2007, 15, 295-306. [CrossRef]

33. Méo, S.C.; Yamazaki, W.; Leal, C.L.V.; de Oliveira, J.A.; Garcia, J.M. Use of strontium for bovine oocyte activation. Theriogenology 2005, 63, 2089-2102. [CrossRef] 
34. Ayoub, M.A.; Hunter, A.G. Parthenogenetic Activation of In Vitro Matured Bovine Oocytes. J. Dairy Sci. 1993, 76, 421-429. [CrossRef]

35. de Oliveira Santos, M.V.; Nascimento, L.E.; Praxedes, É.A.; Borges, A.A.; Silva, A.R.; Bertini, L.M.; Pereira, A.F. Syzygium aromaticum essential oil supplementation during in vitro bovine oocyte maturation improves parthenogenetic embryonic development. Theriogenology 2019, 128, 74-80. [CrossRef] [PubMed]

36. Zuo, Z.; Niu, Z.; Liu, Z.; Ma, J.; Qu, P.; Qiao, F.; Su, J.; Zhang, Y.; Wang, Y. The effects of glycine-glutamine dipeptide replaced l-glutamine on bovine parthenogenetic and IVF embryo development. Theriogenology 2020, 141, 82-90. [CrossRef] [PubMed]

37. Dalvit, G.; Llanes, S.P.; Descalzo, A.; Insani, M.; Beconi, M.; Cetica, P. Effect of alpha-tocopherol and ascorbic acid on bovine oocyte In Vitro maturation. Reprod. Domest. Anim. 2005, 40, 93-97. [CrossRef] [PubMed]

38. Thiyagarajan, B.; Valivittan, K. Ameliorating effect of vitamin e on In Vitro development of preimplantation buffalo embryos. J. Assist. Reprod. Genet. 2009, 26, 217-225. [CrossRef]

39. Adeldust, H.; Zeinoaldini, S.; Kohram, H.; Roudbar, M.A.; Joupari, M.D. In Vitro maturation of ovine oocyte in a modified granulosa cells co-culture system and alpha-tocopherol supplementation: Effects on nuclear maturation and cleavage. J. Anim. Sci. Technol. 2015, 57, 27. [CrossRef]

40. Tareq, K.M.A.; Akter, S.; Khandoker, M.A.M.Y. Selenium and vitamin E improve the In Vitro maturation, fertilization and culture to blastocysts of porcne oocytes. J. Reprod. Dev. 2012, 58, 621-628. [CrossRef]

41. Yashiro, I.; Tagiri, M.; Ogawa, H.; Tashima, K.; Takashima, S.; Hara, H.; Hirabayashi, M.; Hochi, S. High revivability of vitrified-warmed bovine mature oocytes after recovery culture with $\alpha$-tocopherol. Reproduction 2015, 149, 347-355. [CrossRef] [PubMed]

42. Maier, C.M.; Chan, P.H. Role of superoxide dismutases in oxidative damage and neurodegenerative disorders. Neuroscientist 2002, 8, 323-334. [CrossRef] [PubMed]

43. Ghanem, N.; Ha, A.N.; Fakruzzaman, M.; Bang, J.I.; Lee, S.C.; Kong, I.K. Differential expression of selected candidate genes in bovine embryos produced In Vitro and cultured with chemicals modulating lipid metabolism. Theriogenology 2014, 82, 238-250. [CrossRef]

44. Corrêa, G.A.; Rumpf, R.; Mundim, T.C.D.; Franco, M.M.; Dode, M.A.N. Oxygen tension during In Vitro culture of bovine embryos: Effect in production and expression of genes related to oxidative stress. Anim. Reprod. Sci. 2008, 104, 132-142. [CrossRef]

45. Ha, A.N.; Lee, S.R.; Jeon, J.S.; Park, H.S.; Lee, S.H.; Jin, J.I.; Sessions, B.R.; Wang, Z.; White, K.L.; Kong, I.K. Development of a modified straw method for vitrification of In Vitro-produced bovine blastocysts and various genes expression in between the methods. Cryobiology 2014, 68, 57-64. [CrossRef] [PubMed]

46. Borcari, N.R.; Santos, J.F.D.; Reigado, G.R.; Freitas, B.L.; Araújo, M.D.S.; Nunes, V.A. Vitamins Modulate the Expression of Antioxidant Genes in Progesterone-Treated Pancreatic $\beta$ Cells: Perspectives for Gestational Diabetes Management. Int. J. Endocrinol. 2020, 2020. [CrossRef] [PubMed]

47. Chen, K.; Lu, P.; Beeraka, N.M.; Sukocheva, O.A.; Madhunapantula, S.R.V.; Liu, J.; Sinelnikov, M.Y.; Nikolenko, V.N.; Bulygin, K.V.; Mikhaleva, L.M.; et al. Mitochondrial mutations and mitoepigenetics: Focus on regulation of oxidative stress-induced responses in breast cancers. Semin. Cancer Biol. 2020. [CrossRef]

48. Zappe, K.; Pointner, A.; Switzeny, O.J.; Magnet, U.; Tomeva, E.; Heller, J.; Mare, G.; Wagner, K.H.; Knasmueller, S.; Haslberger, A.G. Counteraction of oxidative stress by Vitamin E affects epigenetic regulation by increasing global methylation and gene expression of MLH1 and DNMT1 dose dependently in Caco-2 cells. Oxid. Med. Cell. Longev. 2018, 2018, 3734250. [CrossRef] [PubMed]

49. Remely, M.; Ferk, F.; Sterneder, S.; Setayesh, T.; Kepcija, T.; Roth, S.; Noorizadeh, R.; Greunz, M.; Rebhan, I.; Wagner, K.H.; et al. Vitamin e modifies high-fat diet-induced increase of DNA strand breaks, and changes in expression and DNA methylation of DNMT1 and MLH1 in C57BL/6J male mice. Nutrients 2017, 9, 607. [CrossRef] 